\title{
High-nuclearity homoleptic and heteroleptic coordination cages based on tetra-capped truncated tetrahedral and cuboctahedral metal frameworks.
}

Stephen P. Argent, Harry Adams, Thomas Riis-Johannessen, John C. Jeffery, Lindsay P. Harding and Michael D. Ward*

\section{Supporting information.}

Ligand $\mathrm{L}^{2}$ was prepared as previously described. ${ }^{1}$

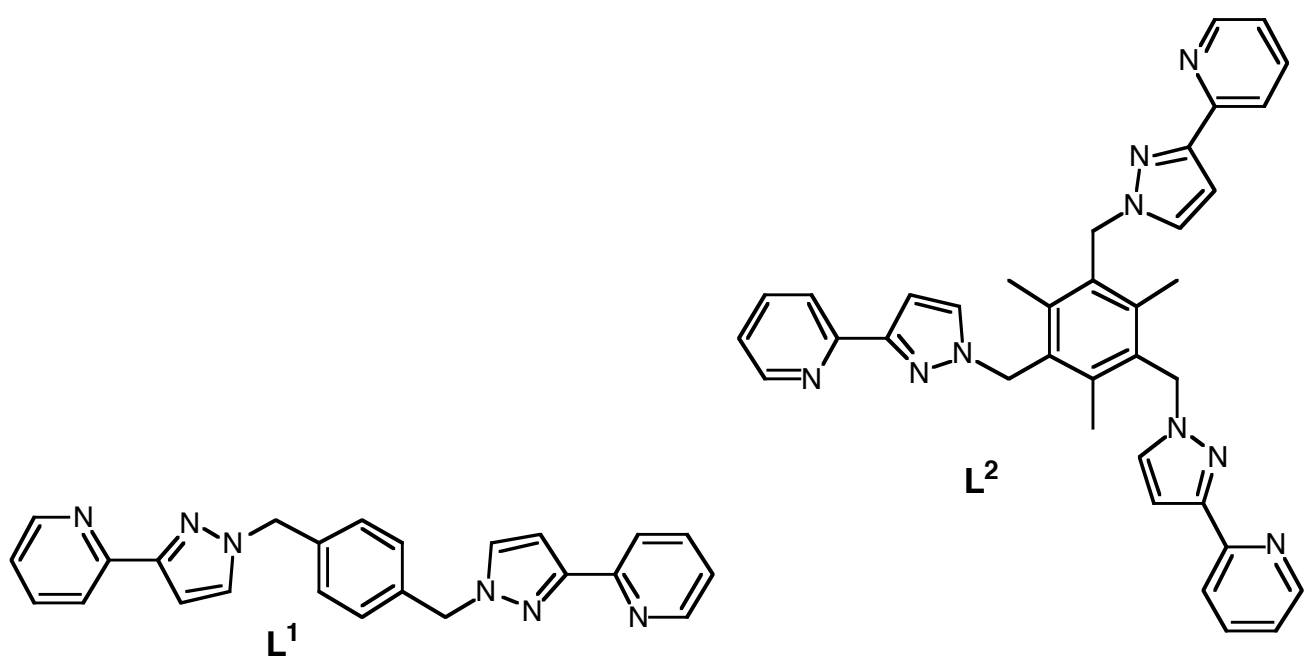

Synthesis of $L^{1}$ : A mixture of 1,4-bis(bromomethyl)benzene (2.00 g, $\left.7.60 \mathrm{mmol}\right), 3-(2-$

pyridyl)pyrazole (2.43 g, $16.7 \mathrm{mmol}),{ }^{2}$ aqueous $\mathrm{NaOH}\left(10 \mathrm{M}, 20 \mathrm{~cm}^{3}\right)$, toluene $\left(50 \mathrm{~cm}^{3}\right)$ and $\mathrm{Bu}_{4} \mathrm{NOH}$ ( $40 \%$ aqueous solution, 3 drops) was stirred at $60^{\circ} \mathrm{C}$ for $1 \mathrm{~h}$. The mixture was diluted with $\mathrm{H}_{2} \mathrm{O}\left(100 \mathrm{~cm}^{3}\right)$ and the organic layer separated, dried over $\mathrm{MgSO}_{4}$ and concentrated before purification by alumina column (5\% THF / dichloromethane) to give $\mathrm{L}^{1}$ as a white solid (Yield: $2.83 \mathrm{~g}, 95 \%) .{ }^{1} \mathrm{H}-\mathrm{NMR}\left(270 \mathrm{MHz}, \mathrm{CDCl}_{3}\right): \delta 8.61\left(2 \mathrm{H}\right.$, ddd, $J 4.9,1.8,0.9$, pyridyl $\left.\mathrm{H}^{6}\right), 7.92$ (2H, ddd, $J 7.9,1.2,0.9$, pyridyl $\left.\mathrm{H}^{3}\right), 7.69\left(2 \mathrm{H}, \mathrm{td}, J 7.9,1.8\right.$, pyridyl $\left.\mathrm{H}^{4}\right), 7.39(2 \mathrm{H}, \mathrm{d}, J 2.4$, pyrazolyl $\left.\mathrm{H}^{5}\right), 7.22\left(4 \mathrm{H}\right.$, s, phenyl), $7.18\left(2 \mathrm{H}\right.$, ddd, $J 7.9,4.9,1.2$, pyridyl $\left.\mathrm{H}^{5}\right), 6.90(2 \mathrm{H}, \mathrm{d}, J 2.1$, pyrazolyl $\left.\mathrm{H}^{4}\right), 5.36\left(4 \mathrm{H}, \mathrm{s}, \mathrm{CH}_{2}\right)$. EIMS $m / z 392\left(M^{+}\right)$. Found: $\mathrm{C}, 72.9 ; \mathrm{H}, 5.0 ; \mathrm{N}, 21.3 \%$.

Required for $\mathrm{C}_{24} \mathrm{H}_{20} \mathrm{~N}_{6}: \mathrm{C}, 73.4 ; \mathrm{H}, 5.1 ; \mathrm{N}, 21.2 \%$. 
Syntheses of complexes. For the homoleptic complex $\left[\mathrm{Cd}_{16}\left(\mu-\mathrm{L}^{1}\right)_{24}\right]\left(\mathrm{ClO}_{4}\right)_{32}$ a mixture of $\mathrm{L}^{1}$ and $\mathrm{Cd}\left(\mathrm{ClO}_{4}\right)_{2} \cdot n \mathrm{H}_{2} \mathrm{O}$, in a 3:2 molar ratio, were dissolved in $\mathrm{MeCN}$ and then single crystals for X-ray and other analyses were grown by slow diffusion of $\mathrm{Et}_{2} \mathrm{O}$ into the solution.

ESMS data for $\left[\mathrm{Cd}_{16}\left(\mu-\mathrm{L}^{1}\right)_{24}\right]\left(\mathrm{ClO}_{4}\right)_{32}: \mathrm{m} / z$ [observed (calculated)] 2777.9 (2780.6), 2300.2 (2300.6), 1957.6 (1957.7), 1699.1 (1700.6), 1499.1 (1500.6), corresponding to $\left\{\left[\mathrm{Cd}_{16}\left(\mu-\mathrm{L}^{1}\right)_{24}\right]\left(\mathrm{ClO}_{4}\right)_{32-x}\right\}^{\mathrm{x}+}(\mathrm{x}=5,6,7,8,9$ respectively $)$.

ESMS data for $\left[\mathrm{Cd}_{16}\left(\mu-\mathrm{L}^{1}\right)_{24}\right]\left(\mathrm{BF}_{4}\right)_{32}: \mathrm{m} / z$ [observed (calculated)] 2720.6 (2719.5), 2252.6 (2251.7), 1918.4 (1917.7), 1667.6 (1667.1), 1472.9 (1472.2), 1316.9 (1316.3) corresponding to $\left\{\left[\mathrm{Cd}_{16}\left(\mu-\mathrm{L}^{1}\right)_{24}\right]\left(\mathrm{BF}_{4}\right)_{32-x}\left(\mathrm{H}_{2} \mathrm{O}\right)_{2}\right\}^{\mathrm{x+}}(\mathrm{x}=5,6,7,8,9,10$ respectively $)$.

ESMS data for $\left[\mathrm{Zn}_{16}\left(\mu-\mathrm{L}^{1}\right)_{24}\left(\mathrm{BF}_{4}\right)_{32}: \mathrm{m} / z\right.$ [observed (calculated)] 2120.5 (2120.4), 1806.2 (1805.1), 1568.8 (1568.6), 1384.8 (1384.7), 1238.3 (1237.5), 1117.9 (1117.1), corresponding to $\left\{\left[\mathrm{Zn}_{16}\left(\mu-\mathrm{L}^{1}\right)_{24}\right]\left(\mathrm{BF}_{4}\right)_{32-\mathrm{x}}\right\}^{\mathrm{x}}(\mathrm{x}=6,7,8,9,10,11$ respectively $)$.

ESMS data for $\left[\mathrm{Zn}_{16}\left(\mu-\mathrm{L}^{1}\right)_{24}\right]\left(\mathrm{ClO}_{4}\right)_{32}: \mathrm{m} / z$ [observed (calculated)] 1606.3 (1606.5), 1414.6 (1416.9), 1269.2 (1265.3), 1037.2 (1037.9), 949.2 (950.4), 874.3 (875.4) corresponding to $\left\{\left[\mathrm{Zn}_{16}\left(\mu-\mathrm{L}^{1}\right)_{24}\right]\left(\mathrm{ClO}_{4}\right)_{32-\mathrm{x}}\right\}^{\mathrm{x}}(\mathrm{x}=8,9,10,12,13,14$ respectively $)$.

For the heteroleptic complex $\left[\mathrm{Cu}_{12}\left(\mu-\mathrm{L}^{1}\right)_{12}\left(\mu^{3}-\mathrm{L}^{2}\right)_{4}\right]\left(\mathrm{BF}_{4}\right)_{24}$, a mixture of $\mathrm{L}^{1}, \mathrm{~L}^{2}$ and $\mathrm{Cu}\left(\mathrm{BF}_{4}\right)_{2}$ in a 3:1:3 molar ratio, was dissolved in $\mathrm{MeNO}_{2}$. Single crystals for X-ray and other analyses were grown by slow diffusion of $\mathrm{Et}_{2} \mathrm{O}$ into this solution.

ESMS data for $\left[\mathrm{Cu}_{12}\left(\mu-\mathrm{L}^{1}\right)_{12}\left(\mu^{3}-\mathrm{L}^{2}\right)_{4}\right]\left(\mathrm{BF}_{4}\right)_{24}: m / z$ [observed (calculated)] 2393.5 (2393.8), 1897.6 (1897.7), 1566.9 (1566.9), 1330.7 (1330.7), 1153.4 (1153.5), 1015.6 (1015.7), corresponding to $\left\{\left[\mathrm{Cu}_{12}\left(\mu-\mathrm{L}^{1}\right)_{12}\left(\mu^{3}-\mathrm{L}^{2}\right)_{4}\right]\left(\mathrm{BF}_{4}\right)_{24-x}\right\}^{x+}(\mathrm{x}=4,5,6,7,8,9$ respectively).

ESMS data for $\left[\mathrm{Co}_{12}\left(\mu-\mathrm{L}^{1}\right)_{12}\left(\mu^{3}-\mathrm{L}^{2}\right)_{4}\right]\left(\mathrm{BF}_{4}\right)_{24}: m / z$ [observed (calculated)] 2379.9 (2379.9), 1886.6 (1886.6), 1557.7 (1557.7), 1322.7 (1322.8), 1146.5 (1146.6), 1009.5 (1009.5), 899.6 (899.9), corresponding to $\left\{\left[\mathrm{Co}_{12}\left(\mu-\mathrm{L}^{1}\right)_{12}\left(\mu^{3}-\mathrm{L}^{2}\right)_{4}\right]\left(\mathrm{BF}_{4}\right)_{24-\mathrm{x}}\right\}^{\mathrm{x+}}(\mathrm{x}=4,5,6,7,8,9,10$ respectively).

ESMS data for $\left[\mathrm{Cd}_{12}\left(\mu-\mathrm{L}^{1}\right)_{12}\left(\mu^{3}-\mathrm{L}^{2}\right)_{4}\right]\left(\mathrm{ClO}_{4}\right)_{24}: \mathrm{m} / z$ [observed (calculated)] 2603.5 (2603.6), 2062.9 (2063.0), 1702.6 (1702.6), 1445.0 (1445.1), 1252.1 (1252.1), corresponding to $\left\{\left[\mathrm{Cd}_{12}\left(\mu-\mathrm{L}^{1}\right)_{12}\left(\mu^{3}-\mathrm{L}^{2}\right)_{4}\right]\left(\mathrm{ClO}_{4}\right)_{24-\mathrm{x}}\right\}^{\mathrm{x}+}(\mathrm{x}=4,5,6,7,8$ respectively $)$.

$\mathrm{C} / \mathrm{H} / \mathrm{N}$ elemental analyses of the crystalline materials complexes were of limited value due to the high uncertainty in the number of lattice solvent molecules. Dried materials were hygroscopic and gave analyses consistent with uptake of several molecules of water per complex molecule. 
Mass spectra were measured on a Bruker MicroTOF mass spectrometer in electrospray positive ion mode. Samples were prepared at a concentration of $c a .2 \mathrm{mg} / \mathrm{mL}$ in $\mathrm{MeNO}_{2}$ or $\mathrm{MeCN}$ and analysed by direct infusion using a Cole Parmer syringe pump at a flow rate of 3 $\mu \mathrm{L} / \mathrm{min}$. Spectra were acquired over an $\mathrm{m} / \mathrm{z}$ range of $50-3000$; several scans were averaged to provide the final spectrum. 


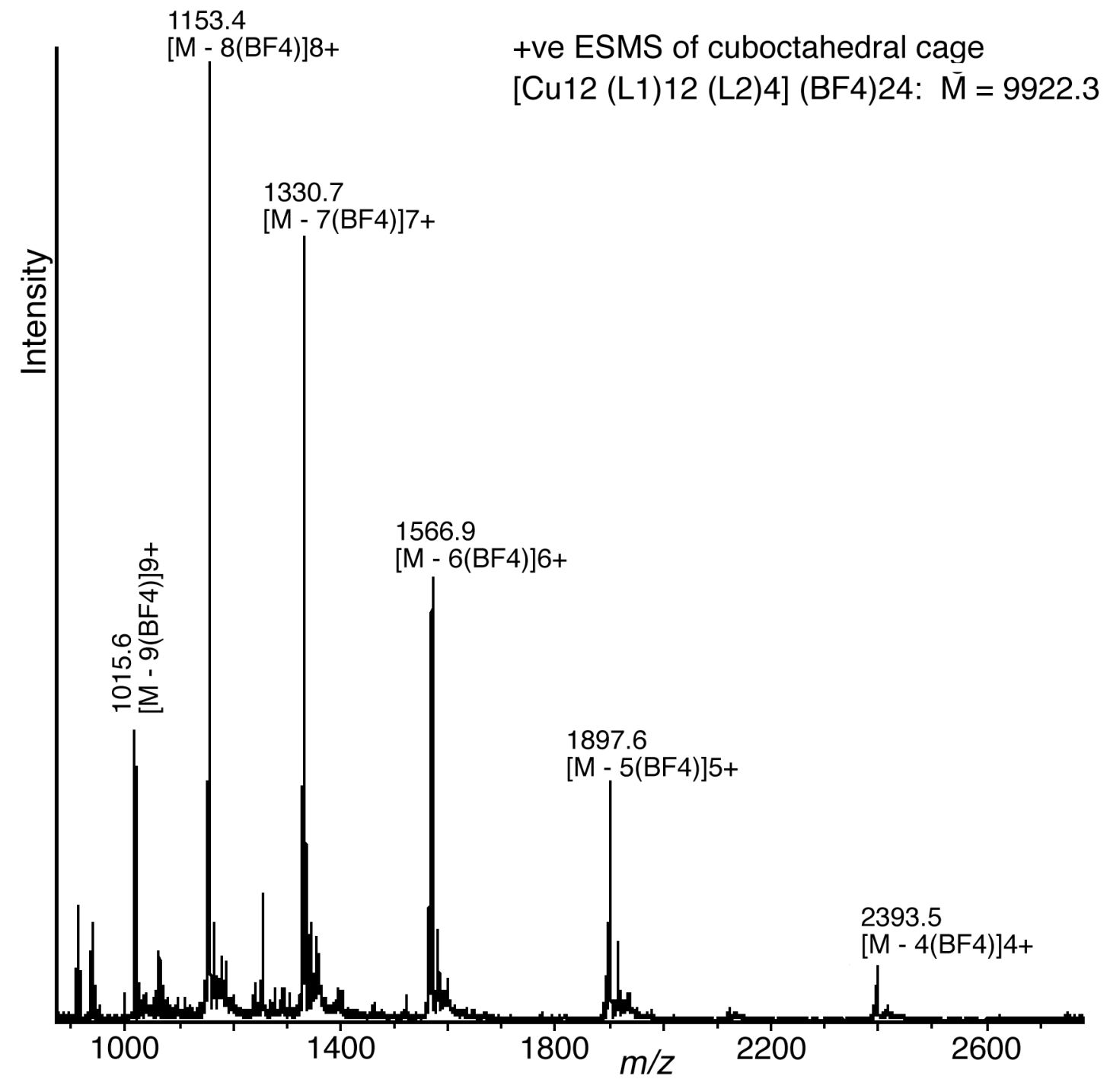




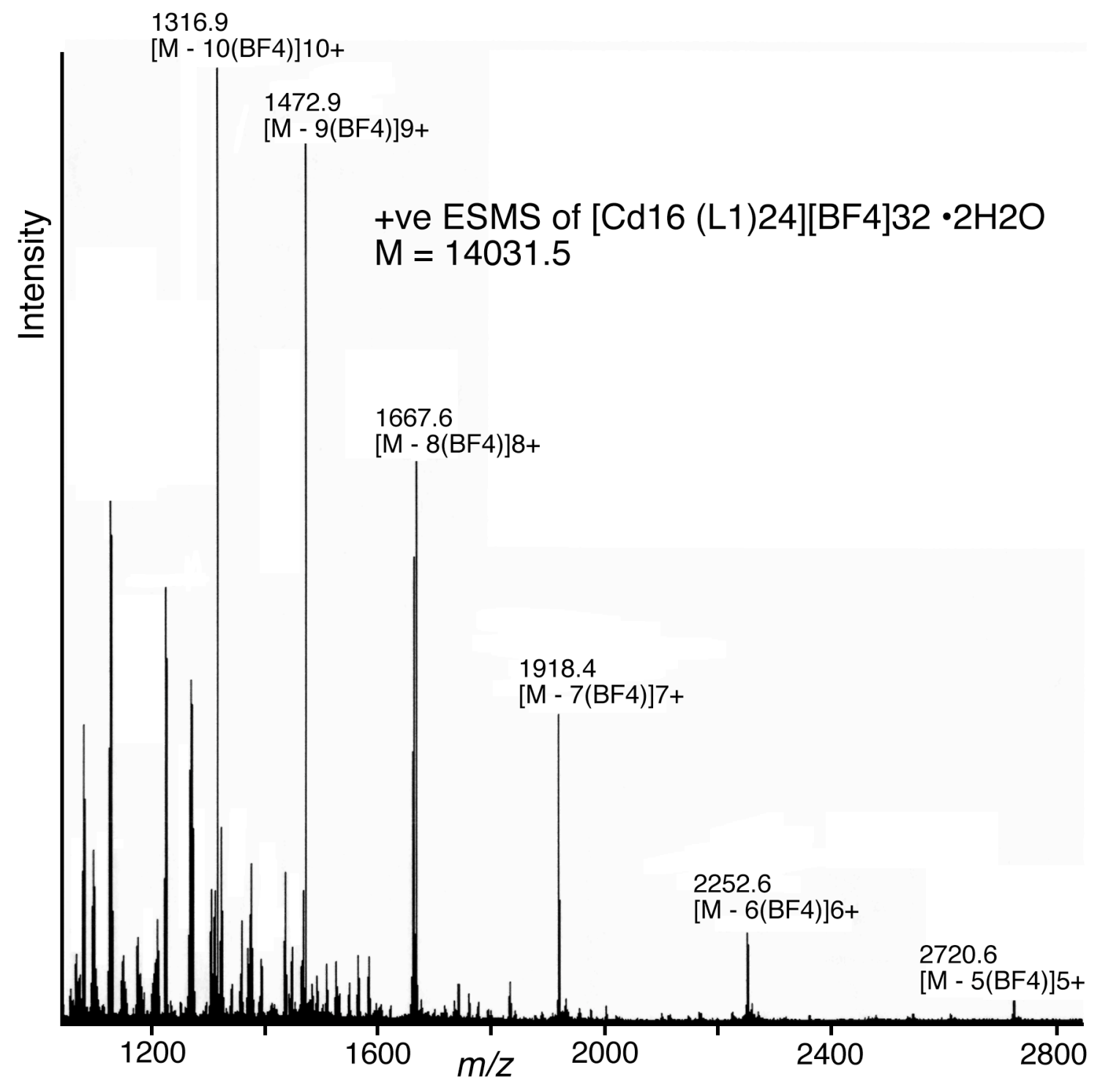


X-ray crystallography. Crystals were removed from the mother liquor, coated with oil, and transferred to the diffractometer as quickly as possible to prevent decomposition due to solvent loss. In both cases the complexes formed large, well-shaped crystals which however scattered weakly, due to the extensive disorder of anions and solvent molecules. Crystallographic data are summarised in the Table below.

\begin{tabular}{|c|c|c|}
\hline Complex & {$\left[\mathrm{Cd}_{16}\left(\mathrm{~L}^{1}\right)_{24}\left(\mathrm{ClO}_{4}\right)_{32}\right] \cdot 23 \mathrm{MeCN}$} & $\begin{array}{l}{\left[\mathrm{Cu}_{12}\left(\mu-\mathrm{L}^{1}\right)_{12}\left(\mu^{3}-\mathrm{L}^{2}\right)_{4}\right]\left(\mathrm{BF}_{4}\right)_{24}} \\
\cdot 20 \mathrm{MeNO}_{2}\end{array}$ \\
\hline Formula* & $\mathrm{C}_{622} \mathrm{H}_{548.5} \mathrm{Cd}_{16} \mathrm{Cl}_{28} \mathrm{~N}_{167} \mathrm{O}_{112}$ & $\mathrm{C}_{452} \mathrm{H}_{430} \mathrm{~B}_{10} \mathrm{Cu}_{12} \mathrm{~F}_{40} \mathrm{~N}_{128} \mathrm{O}_{40}$ \\
\hline Formula weight* & 14945.78 & 9985.82 \\
\hline Diffractometer & Bruker PROTEUM & Bruker SMART-1000 \\
\hline$T(\mathrm{~K})$ & $100(2)$ & $150(2)$ \\
\hline $1(\AA)$ & 1.54178 & 0.71073 \\
\hline Crystal system & Triclinic & Monoclinic \\
\hline Space group & $\mathrm{P}-1$ & $\mathrm{C} 2 / \mathrm{c}$ \\
\hline $\mathrm{a}(\AA)$ & $29.7224(8)$ & $24.840(7)$ \\
\hline $\mathrm{b}(\AA)$ & $30.1896(8)$ & $50.544(13)$ \\
\hline$c(\AA)$ & $52.4872(13)$ & $48.629(12)$ \\
\hline $\mathrm{a}\left({ }^{\circ}\right)$ & $87.5810(10)$ & 90 \\
\hline $\mathrm{b}\left({ }^{\circ}\right)$ & $79.9780(10)$ & $102.003(5)$ \\
\hline$g\left({ }^{\circ}\right)$ & $70.1050(10)$ & 90 \\
\hline$V\left(\AA^{3}\right)$ & $43603(2)$ & $59720(27)$ \\
\hline Z & 2 & 4 \\
\hline$D_{\text {calc }}\left(\mathrm{Mg} / \mathrm{m}^{3}\right)^{*}$ & 1.138 & 1.104 \\
\hline$\mu\left(\mathrm{mm}^{-1}\right)$ & 4.394 & 0.493 \\
\hline $\mathrm{F}(000)$ & 15179 & 20464 \\
\hline Crystal size (mm) & $0.25 \times 0.20 \times 0.10$ & $0.55 \times 0.25 \times 0.13$ \\
\hline Reflections collected & 232145 & 173661 \\
\hline $\begin{array}{l}\text { Independent } \\
\text { reflections }\end{array}$ & $118370[\mathrm{R}(\mathrm{int})=0.0501]$ & $39038[\mathrm{R}(\mathrm{int})=0.1423]$ \\
\hline $\begin{array}{l}\text { Data / restraints / } \\
\text { parameters }\end{array}$ & 118370 / 41577 / 3875 & 39038 / 5183 / 1430 \\
\hline Goodness-of-fit on $\mathrm{F}^{2}$ & 1.396 & 0.812 \\
\hline $\mathrm{R} 1[\mathrm{I}>2 \operatorname{sigma}(\mathrm{I})]$ & 0.1269 & 0.0968 \\
\hline wR2 & 0.3820 & 0.2943 \\
\hline
\end{tabular}

* Some of the anions are missing from this formula as they could not be located due to extensive disorder; see text below.

After integration of the raw data and merging of equivalent reflections, an empirical absorption correction was applied (SADABS) based on comparison of multiple symmetry-equivalent 
measurements. ${ }^{3}$ The structures were solved by direct methods and refined by full-matrix least squares on weighted $F^{2}$ values for all reflections using the SHELX suite of programs. ${ }^{4}$

In both cases the large size of the structure, weak diffraction, and extensive disorder in the anionand solvent-filled cavities resulted in a data set of limited quality, even using a rotating-anode source. In order to minimise the number of parameters in the refinement, all atoms except the metals were refined with isotropic thermal parameters. To reduce the computational time taken for each refinement cycle 'blocks' were used to refine the anions and solvent molecules, and several overlapping portions of the complex cation separately. Geometric similarity restraints (SAME) were applied to all pyrazolyl-pyridine, phenyl-ring, tetrahedral anions, and solvent moieties.

For $\left[\mathrm{Cd}_{16}(\mathrm{xyp})_{24}\left(\mathrm{ClO}_{4}\right)_{32}\right] \cdot 23 \mathrm{MeCN}$, of the expected 32 perchlorate anions 30 were located in the electron-density map, two having site occupancies of 0.5 and four having site occupancies of 0.75 to give a sum of 28 in the asymmetric unit. Unresolved disorder of the anions resulted in many atoms having high thermal parameters, nine of which have been fixed at 0.25 . Several large residual electron-density peaks close to $(<1.5 \mathrm{~A}) \mathrm{Cd}$ atoms are probably caused by one or more of (i) limited efficacy of the absorbtion correction; (ii) low resolution of the structure due to weak high angle data; (iii) minor components of unresolved static disorder in the cage conformation. A 'Squeeze' function was applied to the data to remove the scattering contributions of several small moieties which could not be satisfactorily modelled as anions or solvent.

For $\left[\mathrm{Cu}_{12}\left(\mu-\mathrm{L}^{1}\right)_{12}\left(\mu^{3}-\mathrm{L}^{2}\right)_{4}\right]\left(\mathrm{BF}_{4}\right)_{24} \cdot 20 \mathrm{MeNO}_{2}$ only ten of the fluoroborate anions could be located, the rest being assumed to be mixed up with disordered solvent molecules; this problem was worse for this complex because the anion contains only light atoms (B, F) which have similar atomic masses to the solvent atoms. Again, a 'Squeeze' function was applied to the data to remove the scattering contributions of several small moieties which could not be satisfactorily modelled as anions or solvent.

In both cases, the structures reported here are the best of numerous attempts. 


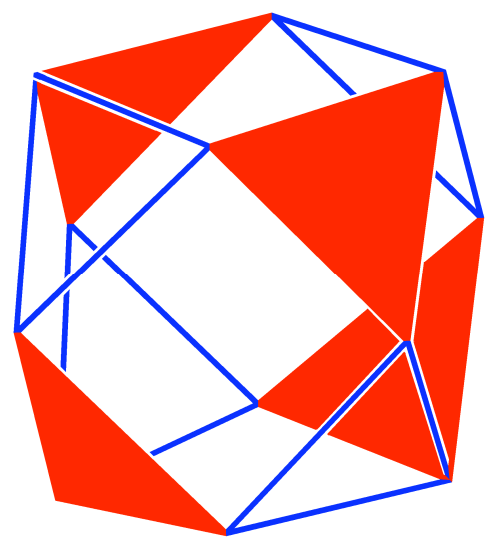

The figure on the left shows the disposition of face-capping ligands $\mathrm{L}^{2}$ (red triangles) and edge-bridging ligands $\mathrm{L}^{1}$ (blue lines) in the cuboctahedral cage $\left[\mathrm{Cu}_{12}\left(\mu-\mathrm{L}^{1}\right)_{12}\left(\mu^{3}-\mathrm{L}^{2}\right)_{4}\right]\left(\mathrm{BF}_{4}\right)_{24}$

We also collected a data set on crystals of $\left[\mathrm{Zn}_{16}\left(\mu-\mathrm{L}^{1}\right)_{24}\right]\left(\mathrm{BF}_{4}\right)_{32}$ which scattered very weakly. A publication-quality structural determination was not possible, but the data was sufficient to allow us to see that that the complex cage has the same structure as that of $\left[\mathrm{Cd}_{16}\left(\mathrm{~L}^{1}\right)_{24}\left(\mathrm{ClO}_{4}\right)_{32}\right] \bullet$ $23 \mathrm{MeCN}$ reported in the main text. Crystallographic data: monoclinic, $C 2 / \mathrm{c} ; a=31.117(3) \AA ; ; b$ $=51.828 \AA ; c=48.797 \AA ; \beta=99.950(2)^{\circ} ; \mathrm{Z}=4 ; \mathrm{V}=77513(9) \AA^{3} ; \mu(\mathrm{Cu}-\mathrm{K} \alpha)=1.281 \mathrm{~mm}^{-1} ; \rho=$ $1.173 \mathrm{~g} \mathrm{~cm}^{-3} .67955$ unique data were collected on a Bruker-PROTEUM diffractometer at 100K and refined to an $R 1$ value of 0.26 . The cage superstructure is apparent but most of the anions and the large number of solvent molecules are severely disordered. In this case the complex cage lies on a $C 2$ axis such that only half of it lies in the asymmetric unit.

1 Bell, Z. R.; McCleverty, J. A.; Ward, M. D. Aust. J. Chem. 2003, 56, 665.

2 Amoroso, A. J.; Cargill Thompson, A. M. W.; Jeffery, J. C.; Jones, P. L.; McCleverty, J. A.; Ward, M. D. J. Chem. Soc., Chem. Commun. 1994, 2751.

3 Sheldrick, G. M. SADABS: A program for absorption correction with the Siemens SMART system, University of Gottingen, Germany, 1996.

4 SHELXTL program system version 5.1; Bruker Analytical X-ray Instruments Inc., Madison, WI, 1998. 